\title{
Kajian Toksisitas dari Fraksi Heksana, Etil Asetat, dan Etanol Daun Soyogik (Sauraia bracteosa DC)
}

\author{
Triyono Mojo a*, Jemmy Abidjulu a, Max.R.J. Runtuwene a \\ aJurusan Kimia, FMIPA, Unsrat, Manado
}

\begin{tabular}{ll}
\hline K A T A K U N C I & A B S T R A K \\
\hline daun soyogik & Telah dilakukan penelitian mengenai Kajian Toksisitas dari Fraksi \\
toksisitas & Heksana, Etil Asetat dan Etanol Daun Soyogik (Saurauia bracteosa DC). \\
LC50 & Daun Soyogik dikeringanginkan sampai kering dan dimaserasi berturut- \\
& turut menggunakan pelarut heksana, etil asetat dan etanol. Uji toksisitas \\
& dilakukan menggunakan metode Brine Shrimp Lethality Test (BSLT), \\
& kemudian diidentifikasi presentasi kematian larva udang menggunakan \\
& analisis probit (LC50). Hasil pengujian toksisitas menunjukkan nilai LC50 \\
& yaitu: fraksi heksana (181,97), fraksi etil asetat (12,97) dan fraksi etanol \\
& $(2,82)$.
\end{tabular}

\begin{tabular}{|c|c|}
\hline KEYWOR D S & A B S T R A C T \\
\hline $\begin{array}{l}\text { leaf soyogik } \\
\text { toxicity } \\
\text { LC }_{50}\end{array}$ & $\begin{array}{l}\text { A research has been about Toxicity of the Fraction Soyogik Leaves } \\
\text { (Saurauia bracteosa DC) from Hexane, Ethyl Acetate and Ethanol. Soyogik } \\
\text { leaves drying till dunes and maceratied successively using hexane, ethyl } \\
\text { acetate and ethanol solvent. Toxicity tests performed using Brine Shrimp } \\
\text { Lethality Test (BSLT) methode. Toxicity testing showed the LC } \text { L }_{50} \text { value is } \\
\text { hexane fraction }(181,97) \text {, ethyl acetate fraction }(12,97) \text { and fraction of } \\
\text { ethanol }(2,82) \text {. }\end{array}$ \\
\hline
\end{tabular}

TERSEDIA ONLINE

09 Februari 2016

\begin{abstract}
1. Pendahuluan
Indonesia merupakan Negara yang kaya akan jenis tanaman. Indonesia memiliki sekitar 30.000 spesies, sekitar 940 di antaranya digunakan sebagai tanaman obat yang sering dimanfaatkan masyarakat sebagai obat traditional. Obat traditional digunakan untuk mengobati berbagai penyakit, baik penyakit dalam maupun penyakit luar dengan cara dimasak dengan air kemudian diminum atau dioleskan/dilekatkan pada bagian tubuh yang akan diobati. Menurut Hyeronimus (2008), obat tradisional telah dikenal oleh masyarakat Indonesia sejak zaman dahulu, selain khasiatnya yang telah turun-temurun digunakan oleh masyarakat, obat ini lebih murah dan mudah didapat, namun diperlukan penelitian yang lebih lanjut karena banyaknya tanaman yang belum diketahui kadar toksisitasnya.

BSLT merupakan teknik analisis untuk mengetahui efek sitotoksik atau kadar toksisitas dari suatu tanaman (Meyer et al., 1982). Kadar
\end{abstract}

toksisitas dari suatu tanaman dapat menunjukkan kemampuan untuk menyembuhkan penyakit seperti kanker. Dalam perkembangan teknologi, telah ditemukan obat-obat antikanker, namun tingginya biaya pengobatan sehingga masyarakat lebih memilih untuk menggunakan obat tradisional. Obat tradisional sangat dipercaya oleh masyarakat mempunyai kelebihan dibandingkan obat modern yaitu memiliki efek samping yang relatif kecil dari pada obat modern. Salah satu jenis tanaman yang dapat dimanfaatkan sebagai obat tradisional adalah soyogik, karena dari peneltian yang dilakukan oleh Runtuwene et al. (2012), bekerja sama dengan Balai Penelitian dan Pengembangan Kementrian Kesehatan menyatakan bahwa, soyogik merupakan salah satu tanaman yang biasa digunakan dalam pengobatan penyakit tumor dan kanker pada etnis Tongsawang di Kabupaten Minahasa Tenggara. Penelitian selanjutnya dilakukan oleh Muaja (2013) dan Maukar et al. (2013), menunjukkan bahwa ekstrak metanol dari daun soyogik mengandung

*Corresponding author: Jurusan Kimia FMIPA UNSRAT, Jl. Kampus Unsrat, Manado, Indonesia 95115; Email address: griffinrambi@ymail.com

Published by FMIPA UNSRAT (2016) 
senyawa fitokimia yaitu fenolik, flavonoid dan tanin, serta bersifat toksik. Berdasarkan informasi yang terpapar diatas, penulis tertarik untuk menganalisis sifat toksisitas dari fraksi heksana, etil asetat dan etanol dari daun soyogik.

\section{Material dan Metode}

Alat yang digunakan adalah blender, timbangan analitik, aluminium foil, kertas saring, evaporator, spatula, tabung reaksi, labu ukur, pipet tetes, corong, erlenmeyer, beaker glass, lampu pijar, ayakan 65 mesh, kaca pembesar.

Bahan yang digunakan adalah daun soyogik, heksana, etil asetat, etanol, larva Artemia salina Leach.

\subsection{Preparasi Sampel}

Daun soyogik yang dipetik dicuci hingga bersih, kemudian dikeringanginkan selama 8 hari untuk mengangkat kadar air. Setelah kering, daun diblender hingga halus seperti serbuk dan diayak dengan ayakan 65 mesh.

\subsection{Ekstraksi Bahan Aktif}

Ekstraksi dilakukan dengan cara maserasi menggunakan tiga pelarut yaitu Heksana, Etil Asetat dan Etanol. Sampel Sebanyak 100 g direndam dengan heksana selama 3 x 24 Jam. Larutan ekstraksi tersebut disaring menggunakan kertas saring sehingga diperoleh filtrat heksana dan residu. Residu kembali dilarutkan dengan etil asetat selama $3 \times 24$ jam. Larutan ekstraksi di saring dengan kertas saring sehingga dihasilkan filtrat etil asetat dan residu. Dan yang terakhir, residu dilarutkan dengan etanol selama 3 × 24 jam. Larutan ekstraksi di saring dengan kertas saring sehingga mendapatkan filtrat etanol dan residu. Ketiga filtrat yang diperoleh selanjutnya dievaporasi menggunakan evaporator, kemudian pelarut diuapkan sampai di peroleh ekstrak kental.

\subsection{Penentuan Kadar Air}

Kadar air ditentukan menggunakan metode Sudamardji (1989). Sampel ditimbang 2 g, setelah itu sampel dimasukan ke dalam oven pada suhu $105{ }^{\circ} \mathrm{C}$ selama 3-5 jam, kemudian dikeluarkan dari oven dan didinginkan dalam desikator selama 30 menit, setelah itu sampel ditimbang. Perlakuan ini dilakukan beberapa kali hingga berat sampel konstan.

\subsection{Uji Toksisitas Menggunakan Metode Brine Shrimp Lethality Test (BSLT)}

\subsubsection{Penyiapan Larva}

Diambil sebanyak $1 \mathrm{~g}$ telur larva $A$. salina Leach, kemudian direndam dalam $2 \mathrm{~L}$ air laut buatan dan diberi penerangan dengan lampu pijar 40-60 watt, serta diaerasi selama 48 jam. Cara pembuatan air laut buatan yaitu dengan melarutkan 40 g garam dalam air hingga volume mencapai $2000 \mathrm{~mL}$, setelah itu disaring (Indrayani et al., 2006 dalam Sangi et al., 2012).

\subsubsection{Penyiapan Larutan Stok}

Masing-masing fraksi disiapkan larutan stok 2000 ppm dengan cara malarutkan 0,2 gram ekstrak dalam air laut buatan hingga mencapai volume $100 \mathrm{~mL}$, kemudian dilakukan pengenceran 1000 ppm, 100 ppm, 10 ppm, 1 ppm. Untuk kontrol (0 ppm) dilakukan tanpa penambahan ekstrak.

\subsubsection{Uji Toksisitas}

Larutan uji dengan konsentrasi 1000, 100, 10, 1 ppm dari masing-masing fraksi dipipet sebanyak 6 $\mathrm{mL}$ dan dimasukkan ke dalam gelas air mineral kemudian dimasukkan 10 ekor larva udang yang telah berumur 2 hari. Pengamatan untuk kematian larva dilakukan selama 24 jam dengan selang waktu 1 jam, setelah itu dihitung nilai $\mathrm{LC}_{50}$ dari data kematian larva tersebut. (Sirait, dalam Sangi et al.,2012).

\section{Hasil dan Pembahasan}

\subsection{Rendemen Ekstrak Daun Soyogik}

Perhitungan rendemen dilakukan untuk mengetahui seberapa banyak bagian yang dapat diekstraksi dari bahan mentah yang akan diuji. Hasil ekstraksi $100 \mathrm{~g}$ daun soyogik memiliki nilai yang berbeda pada tiga fraksi. Fraksi heksan diperoleh ekstrak sebanyak $0,747 \mathrm{~g}$ dengan persen rendemen yaitu $0,7474 \%$. Fraksi etil asetat diperoleh ekstrak sebanyak 2,1856 g dengan persen rendemen $2,1856 \%$. Sedangkan pada fraksi etanol diperoleh ekstrak sebanyak 4,74 g dengan persen rendemen $4,74 \%$. Hasil rendemen tertinggi diperoleh pada fraksi etanol, hal ini menunjukkan bahwa bagian terbesar yang dapat diekstraksi dari daun soyogik bersifat polar. Menurut Harbone (1987), faktorfaktor seperti kadar air, ukuran sampel, pelarut dan teknik ekstrasi sangat mempengaruhi nilai persen rendemen ekstrak yang diperoleh dari hasil ekstrasi pada suatu sampel uji.

\subsection{Kadar Air}

Untuk melakukan suatu analisis, sampel harus memiliki kadar air yang rendah agar terhindar dari aktivitas mikroba dan memiliki ketahanan dalam penyimpanan. Menurut Nugrahani (2005), sebagian besar perubahan bahan pangan terjadi dalam media air, baik yang ditambahkan atau yang berasal dari bahan itu sendiri. Kadar air yang tinggi akan menghambat proses ekstrasi. Kadar air yang tinggi akan mengakibatkan pelarut sulit untuk menembus dinding-dinding sel pada saat proses ekstraksi pada suatu bahan uji. Oleh karena itu, perlu dilakukan pengujian persen kadar air pada sampel sebelum dilakukan pengujian lebih lanjut. Persen kadar air dari serbuk daun soyogik yaitu 8,7 \%. Kadar air pada serbuk daun soyogik diturunkan dengan cara pengeringan menggunakan oven pada suhu 105$110^{\circ} \mathrm{C}$.

\subsection{Ekstraksi Daun Soyogik}

Untuk ekstraksi daun soyogik, metode maserasi digunakan untuk memperoleh komponen 
aktif. Daun soyogik yang sudah menjadi serbuk direndam dengan tiga jenis pelarut yang memiliki tingkat kepolaran yang berbeda yaitu heksana, etil asetat dan etanol. Hal ini bertujuan untuk dapat menarik komponen aktif dengan tingkat kepolaran dari setiap pelarut dan diperoleh fraksi heksana, fraksi etil asetat dan fraksi etanol. Maserasi dengan heksan untuk memperoleh komponen aktif yang bersifat non polar, dengan etil asetat untuk memperoleh komponen aktif yang bersifat semi polar dan etanol untuk memperoleh komponen aktif yang bersifat polar. Maserasi pada serbuk daun soyogik dilakukan 3 × 24 jam untuk setiap fraksi, agar supaya pelarut mempunyai waktu interaksi dengan sampel lebih lama dan banyak untuk melakukan pemecahan dinding dan membran sel sampel. Menurut Silva et al. (1998), selama proses maserasi akan terjadi perbedaan tekanan antara di dalam sel dan di luar sehingga senyawa metabolit sekunder yang ada di dalam sitoplasma akan keluar dan terlarut dalam pelarut yang digunakan.

\subsection{Uji Toksisitas}

Dalam uji toksisitas, kematian larva diukur pada konsentrasi 1000, 100, 10, 1 dan 0 ppm. Larva yang digunakan berumur 48 jam, karena menurut McLaughlin dan Roger (1998), kondisi larva yang tepat untuk uji hayati yaitu pada usia 48 jam, dimana anggota tubuh larva sudah lengkap (Muaja, 2013). Pengujian ini dilakukan dua kali pengulangan, setiap penujian dilakukan duplo, jadi total larva yang digunakan dalam uji toksisitas tersebut sebanyak 600 ekor untuk tiga fraksi daun soyogik. Jumlah kematian larva pada setiap gelas uji dalam berbagai konsentrasi perlakuan FH, FEA dan FE dari daun soyogik ditunjukkan pada tabel di bawah ini.

Tabel 3. Jumlah kematian larva dari variasi konsentrasi FH, FEA dan FE daun soyogik terhadap kematian larva Artemia salina Leach selama 24 jam

\begin{tabular}{|c|c|c|c|c|c|}
\hline \multicolumn{6}{|c|}{ Fraksi Heksan } \\
\hline \multirow[t]{2}{*}{ Ulangan } & \multicolumn{5}{|c|}{ Konsentrasi (ppm) } \\
\hline & 1000 & 100 & 10 & 1 & Kontrol \\
\hline 1 & 6 & 5 & 2,5 & 1,5 & 0 \\
\hline 2 & 6,5 & 5 & 3 & 1,5 & 0 \\
\hline Rata-rata & 6,25 & 5 & 2,75 & 1,5 & 0 \\
\hline \multicolumn{6}{|c|}{ Fraksi Etil Asetat } \\
\hline \multirow[t]{2}{*}{ Ulangan } & \multicolumn{5}{|c|}{ Konsentrasi (ppm) } \\
\hline & 1000 & 100 & 10 & 1 & Kontrol \\
\hline 1 & 10 & 7,5 & 5,5 & 4 & 0 \\
\hline 2 & 9 & 6,5 & 5,5 & 3,5 & 0 \\
\hline Rata-rata & 9,5 & 7 & 5,5 & 3,75 & 0 \\
\hline \multicolumn{6}{|c|}{ Fraksi Etanol } \\
\hline \multirow[t]{2}{*}{ Ulangan } & \multicolumn{5}{|c|}{ Konsentrasi (ppm) } \\
\hline & 1000 & 100 & 10 & 1 & Kontrol \\
\hline 1 & 10 & 9 & 6,5 & 5,5 & 0 \\
\hline 2 & 10 & 9 & 5,5 & 3,5 & 0 \\
\hline Rata-rata & 10 & 9 & 6 & 4,5 & 0 \\
\hline
\end{tabular}

Dari tabel 3, menunjukkan rata-rata kematian larva secara signifikan terjadi pada konsentrasi 1000 dan 100 ppm, artinya semakin tinggi konsentrasi akan berbanding lurus dengan kematian larva. Jumlah rata-rata kematian larva yang tertinggi terjadi pada FE diikuti secara berturutturut FEA dan FH. Penelitian ini menunjukkan bahwa fraksi dari daun soyogik bersifat toksik terhadap larva Artemia salina Leach.

Tabel 4. Persamaan Regresi dan Harga LC5o dari Fraksi Daun Soyogik

\begin{tabular}{lll}
\hline Fraksi & Persamaan Regresi & LC50 \\
\hline Heksana & $\mathrm{y}=0,754 \mathrm{x}+3,94$ & 181,97 \\
Etil asetat & $\mathrm{y}=0,818 \mathrm{x}+4,093$ & 12,59 \\
Etanol & $\mathrm{y}=1,069 \mathrm{x}+4,519$ & 2,82 \\
\hline
\end{tabular}


Menurut Meyer et al (1982), suatu ekstrak memiliki aktivitas toksik apabila dapat membunuh $50 \%$ hewan uji pada konsentrasi $<1000 \mu \mathrm{g} / \mathrm{mL}$. Nilai LC50 < $30 \mu \mathrm{g} / \mathrm{mL}$ bersifat sitotoksik, 30-200 $\mu \mathrm{g} / \mathrm{mL}$ berpotensi sebagai antibakteri, sedangkan 200-1000 $\mathrm{\mu g} / \mathrm{mL}$ berpotensi sebagai pestisida (McLaughlin et al., 1991). Berdasarkan pernyataan diatas dapat disimpulkan bahwa, $\mathrm{FH}$ berpotensi sebagai antibakteri, sedangkan FEA dan FE bersifat sitotoksik.

\section{Kesimpulan}

Fraksi heksana, etil asetat dan etanol dari daun soyogik mempunyai potensi toksisitas terhadap larva Artemia salina Leach dan dari nilai LC50 yang diperoleh dapat disimpulkan bahwa fraksi haksana memiliki potensi sebagai antibakteri, sedangkan fraksi etanol dan etil asetat bersifat sitotoksik.

\section{Daftar Pustaka}

Harborne, J.B. 1987. Metode Fitokimia. Terjemahan: Pandawinata, $\mathrm{K}$ dan Soediro, I. Institut Teknologi Bandung, Bandung.

Hyeronimus, S. B. 2006. Ragam dan Khasiat Tanaman Obat. Edisi Pertama. Argo Media, Jakarta.

Indrayani, L., Soetjipto, H., Sihasale, L. 2006. Skrining Fitokimia dan Uji Toksisitas Ekstrak Daun Pecut Kuda (Stachytarpheta jamacensis L. Vahl) Terhadap Larva Udang Artemia Salina Leach. Fakultas Sains dan Matematika Universitas Kristen Satya Wacana, Salatiga. Journal. 12 : 57-61.

McLaughlin, J.L., Chang, C. J., dan Smith, D. L. 1991. Bench-Top, Bioassay for The Discovery of Bioactive Naturals Products, An Update, Natural Product Chemistry. Elseiveir. Amsterdam.

McLaughlin, J.L dan Rogers, L.L. 1998. The Use Of Biological Assays To Evaluate Botanicals. Drug Information Journal. 32:513-524.
Maukar, A. M., M. R. J. Runtuwene, \& J. Pontoh. 2013. Analisis Kandungan Fitokimia dari Uji Toksisitas Ekstrak Metanol Daun Soyogik (Sauraula bracteosa DC) dengan Menggunakan Metode Maserasi. Jurnal IImiah Sains. 13(2): 98-101.

Meyer, B. N., N. R. Ferrigni, J. E. Putnam, L. B. Jacobsen, D. E. Nichols \& J. L. McLaughlin. 1982. Brine Shrimp: A Covenient General Bioassay for Active Plant Constituens. Planta Medica. 45:31-34.

Muaja, A. D. 2013. Uji Toksisitas dengan Metode BSLT dan Analisis Daun Soyogik (Saurauia bracteosa DC) dengan Metode Soxhletasi. [Skripsi]. FMIPA UNSRAT, Manado.

Nugrahani, M. D. 2005. Perubahan karakteristik dan Kualitas Protein pada Mie Basah Matang Yang mengandung Formadehiddan Boraks. Reporsitory.ipb.ac.id Yang Diakses Pada 2005.

Runtuwene, M. R. J., S. Walingkas, M. Rantung, A. Tumbelaka \& M. Lampian. 2012. Riset Khusus Explorasi Pengetahuan Lokal Etnomedisin Dan Tumbuhan Obat Di Indonesia Berbasis Komunitas Etnis Tongswang. Laporan. 7109.00404. Lembaga Penelitian Universitas Sam Ratulangi Bekerja Sama Dengan Badan Litbang Kesehatan.

Sangi, M. S., L. I. Momuat \& M. Kumaunang. 2012. Uji Toksisitas dan Skrining Fitokimia Tepung Gabah Pelepah Aren (Arenga pinnata). J. IImiah S. 12: 128-134.

Silva, G.L., I.S. Lee, \& A.D. Kinghom. 1998. Special Problem with Extraction of Plants in Chanell R.JP. (ed) Methods in Biotechnology 4. Natural Product Isolation Human Press, Totowa, New Jersey, USA.

Sirait, B. M. 2001. Potensi Bioktif Tumbuhan Kasai, Tabat Barito, Bratawali, Bangle dan Sambung Nyawa: Penapisan Fitokimia dan Toksisitas Fraksi Aktif [skripsi]. FMIPA IPB, Bogor. 